\title{
International Journal of Literature and Arts
}

2016; 4(1-1): 5-12

Published online November 2, 2015 (http://www.sciencepublishinggroup.com/j/ijla)

doi: $10.11648 /$ j.ijla.s.2016040101.12

ISSN: 2331-0553 (Print); ISSN: 2331-057X (Online)

\section{On Comparative Literature}

\section{EImas Sahin}

Department of Turkish Language and Literature, Faculty of Arts and Science, Çağ University, Mersin, Turkey

\section{Email address:}

elmassahin@cag.edu.tr

\section{To cite this article:}

Elmas Sahin. On Comparative Literature. International Journal of Literature and Arts. Special Issue: World Literature, Comparative Literature and (Comparative) Cultural Studies. Vol. 4, No. 1-1, 2016, pp. 5-12. doi: 10.11648/j.ijla.s.2016040101.12

\begin{abstract}
This study focuses on issues such as what comparative literature is or not, how it is perceived today, what its benefits are, what kinds of mistakes are made in theory and practice in comparisons of the texts. The term 'literature' has been scene of plentiful discussions from the Greek and Latin civilizations to our age. From philosophical approaches to literary discourses, from poetry to tragedy, from story to novel, and the other literary genre, numerous masterpieces have been written, discussed and criticized. From the East to the West and from the North to the South the writers have been influenced by each other's works, the world has welcomed with an enormous world literature. Thus, comparative approaches, interactions and interests to the texts behind the boundaries across national literatures led to the source of the birth of 'comparative literature' to be discussed in scientific context, to be theorized, and especially flourished during 19th century. Here I want to emphasize inaccuracies in perceptions and practices of comparative literature today, rather than to the historical development of comparative literature as an academic discipline interested in the literature of two or more different languages, cultures or nations.
\end{abstract}

Keywords: Comparative Literature, Cultural Studies, World Literature, Theory, Practice

\section{Introduction}

Comparative literature is a study of the literary texts written in different languages by the most common and simple meaning, such that this means a study behind linguistic, literary and cultural boundaries.

In the words of Rene Wellek, "comparative literature" as a study of relationships between two or more literatures (Wellek \& Warren, 1949, p. 40) has been interpreted so widely or misinterpreted so much and the term has been changed and developed so fast from early decades of 19th century to present. In one sense, today comparative literature embraces 'comparative cultural studies' that have borrowed some elements (theories and methods) from comparative literature as Totosy de Zepetnek argues in his article "From Comparative Literature Today toward Comparative Cultural Studies." He describes "Comparative cultural Studies" as an approach with three areas of theoretical content:

1) To study literature (text and/or literary system) with and in the context of culture and the discipline of cultural studies;

2) In cultural studies itself to study literature with borrowed elements (theories and methods) from comparative literature; and

3) To study culture and its composite parts and aspects in the mode of the proposed "comparative cultural studies" approach instead of the currently reigning single-language approach dealing with a topic with regard to its nature and problematics in one culture only.

Comparative literature or the comparative studies of 'other's literatures, languages and cultures behind the boundaries; Literary studies with comparative cultural approaches to the other cultures as well as the other languages and literatures make numerous contributions on literary studies, literary criticism and theory, literary history, translation, area studies and global studies in the result of contexts of literature and the interactions of local or a national literature with the other national literature/s.

In this term, the scholars interested in comparative literature should embrace literary works and cultures in multiple languages from a comparative perspective. Whereas when a scholar examines only one nation's literature, literary works or writers this will not be a comparative study.

To study or compare writers of only a national literature (for instance the poets of modern Turkish literature) will be a literary history or a literary research on that country. Such a study will reveal literary values, progress or development of 
that nation's literature, language and culture. However when $\mathrm{s} /$ he studies on different literatures, languages or cultures (for example the poets of modern Turkish literature and English literature) this will be a comparative study.

\section{A Short History of Comparative Literature}

The word 'comparative' derived from Latin comparativus, from comparare is an observation or judgment of similarities or dissimilarities between two or more branches of science or subjects of study such as comparative literature, comparative religion, comparative language and soon.

The word comparative as an adjective was firstly used by Shakespeare in his play King Henry IV, Part I in 1597 in the words Falstaff's uttered to Hal, Prince of Wales: "...the most comparative, rascalliest, sweet young prince." (Shakespeare, 1773, p. 235). In 1598 Francis Meres used the term as adjective in the section titled "A Comparative Discourse of Our English Poets with the Greek, Latin and Italian Poets" in his book Palladis Tamia subtitled "Wits Treasury"

Meres compares Greek poets of great antiquity (like Homer, Orpheus, Linus and Musaeus), the ancient Latin poets (like Jovianus Pontanus, Politianus, Marullus Tarchaniota) and the ancient Italian poets, (like Livius Andronicus, Ennius and Plautus) to forerunners of English literature such as Chaucer, Gower and Lydgate. (http://www.elizabethanauthors.org/palladis.htm). Homer reputed the prince of Greek poets, and Petrarch of Italian poets and Chaucer accounted the god of English poets are compared and contrasted together with the other ancient poets of the antiquity. We can say taht it is the first article of studies of comparative literature.

Then the term was used in some captions of seventeenth-and eighteenth-century books. After these attempts at the beginnings of the nineteenth century in France the words 'comparative' and 'literature' were used together as a phrase in several course books.

Fernand Baldensperger largely tells in the first part (Littérature Comparée: Le Mot et la chose) of his book (together with Paul Hazard) titled Revue de littérature comparée historically developments in French literature "Noël and Laplace begin to publish their courses "Comparative Literature" in 1816, and Villemain puts a preface for Tableau of the eighteenth century (during 1827 and 1828) speaks of a "comparative study of literature." J.J. Ampère, in his Athenaeum's opening lesson Marseille (1830) provides "comparative history of arts and literal temperature in all nations" whose philosophy must leave literature and the arts." (Baldensperger, 1921, p. 8)

Ampère brings together various studies, it is observed that all his work is relate to the history of comparative literature (1833). Chaudes- Aigues, modern writers of France, in 1841, will stick to "The history of comparative literature "; Ville main and Puibusque, in 1842 and 1843, to "the comparative history of literally tures." Similarly, Benloew offers in Dijon in 1849 "Introduction to the comparative history of literature. (Baldensperger, 1921, p. 9)

On the other hand, the first time in English the phrase "comparative literature" in 1848 was used in an unpublished letter by Matthew Arnold who translated Ampère's use of "histoire comparative." (Wellek \& Warren, Theory of Literature, 1949, p. 38).

In the private letter he wrote his mother unpublished till 1895, Mathew Arnold uses the phrase 'comparative literature' "How plain it is now, though an attention to the comparative literatures for the last fifty years might have instructed any one of it, that England is in a certain sense far behind the Continent In conversation, in the newspapers, one is so struck with the fact of the utter insensibility, one may say, of people to the number of ideas and schemes..." (Arnold, 1895, p. 10)

Arnold defines the term in a conference, dated 14 November 1857, titled "On the Modern Element in Literature," printed in Macmillan's Magazine, February 1869, in these words "Everywhere there is connexion, everywhere there is illustration: no single event, no single literature, is adequately comprehended except in its relation to other events, to other literatures. (Arnold, 1914, p. 456)

When we shortly look at books published on comparative literature, although it firstly appeared in the title of the book named Irish scholar Hutcheson Macaulay Posnett's Comparative Literature in 1886 , it arose as an academic discipline in the nineteenth century.

Today we recognize the contributions of the books such as Paul Van Tieghem's La Littérature Comparée (1931, René Wellek and Austin Warren's Theory of Literature (1942), Marius-François Guyard's La Littérature Comparée (1951), Rene Wellek's The Crisis of Comparative Literature; Concepts of Criticism (1963), Claude Pichois and A.M. Rousseau's La littérature comparée (1967), Ulrich Weisstein's Einführung in die vergleichende Literaturwissenschaft (1968), Jan Brandt Corstius's Introduction to the Comparative Study of Literature (1968), Henry Gifford's Comparative Literature (1969), Siegbert S. Prawer's Comparative Literature Studies: An Introduction (1973), C:L: Wrenn's The Idea of Comparative Literature (1973), John B. Alphonso-Karkal's Comparative World Literature: Essays (1974), Hugo Dyserinck's Komparatistik: eine Einführung (1977), Robert J. Clement's Comparative Literature as Academic Discipline: A Statement of Principles, Praxis, Standards (1978), Gerhard R. Kaiser's Einführung in die Vergleichende Literaturwissenschaft (1980), Swapan Majundar's Comparative Literature: Indian Dimensions (1987), Peter V. Zima and Johann Strutz's Komparatistik. Einfiihrung in die Vergleichende Literaturwissenschafi (1992), Yves Chevrel's La Littérature Comparée (1989), Gurbhagat Singh's Differential Multilogue: Comparative Literature and National Literatures (1991), André Lefevere's Translating Literature: Practice and Theory in a Comparative Literature Context (1992), Susan Basnett's Comparative Literature: A Critical Introduction (1993), Claudio Guillen's The Challenge of Comparative Literature (1993); Charles Bernheimer's Comparative Literature in the Age of Multiculturalism (1995), 
Rey Chow's In the Name of Comparative Literature (1995) George Steiner's What is Comparative Literature (1995), Steven Tötösy de Zepetnek's Comparative Literature: Theory, Method, Application (1998), Takayuki Yokota-Murakami's Don Juan East/West: On the Problematics of Comparative Literature (1998), John T. Kirby's The Comparative Reader: A Handlist of Basic Reading in Comparative Literature (1998), Gayatri Chakravorty Spivak's The Death of a Discipline (2003), Haun Saussy's Comparative Literature in An Age of Globalization (2006), Dominique Jullien's Foundational Texts of World Literature (2011), Jacob Edmond's A Common Strangeness: Contemporary Poetry, Cross-Cultural Encounter, Comparative Literature (2012), Steven Tötösy de Zepetnek and Tutun Mukherjee's Companion to Comparative Literature, World Literatures, and Comparative Cultural Studies (2013) among the studies of literatures behind the boundaries in the world.

As for Turkish literature İnci Enginun's Mukayeseli Edebiyat (Comparative Literature 1992), Kamil Aydın's Karşılaştırmalı Edebiyat: Günümüz Postmodern Bağlamda Algllanıs (Comparative Literature and Its Perception in Today's Postmodern Context 2008), Emel Kefeli's Karşılaştırmalı Edebiyat Incelemeleri (Comparative Literature Studies 2000), Gürsel Aytaç's Karşılaştırmalı Edebiyat Bilimi (The Science of Comparative Literature 1997) Ali Osman Öztürk's Karşılaştırmalı Edebiyat Araştırmaları (Comparative Literature Research 1999) Şeyda Ülsever's Karşılaştırmalı Edebiyat ve Edebi Çeviri (Comparative Literature and Literary Translation 2005), Binnaz Baytekin's Kuramsal ve Uygulamalı Karşılaştırmalı Edebiyat Bilim (Theoretical and Applied Comparative Literature 2006), Mesut Tekşan's Karşılaştırmalı Edebiyat Bilimi (The Science of Comparative Literature 2012) are remarkable books for comparative literature.

It is the fact that several comparative critical approaches from Plato to Aristotle, Longinus, Horace, Virgil, Dante, Seneca, Descartes, Spencer, Milton, Marlowe, Shakespeare, Pope, Swift, Dryden, Johnson, Fielding, Coleridge, Wordsworth, Keats, Shelley, Richardson, Addison, Byron, Poe, Goethe and Arnold, Voltaire, Flaubert, Balzac, Lamartine, Diderot, Boileau, Taine, Sainte-Beuve have opened a huge window towards the Comparative Literature or the Comparative Study of different Literatures, and by the time the term Weltliteratur (World Literature) used by Goethe in 1827 was born, and comparative studies between literatures have been popular.

\section{Theory and Practice}

What comparative literature means today is very different from previous discourses in global context. Cultural studies take us on reconsideration or redefinition of the term of comparative literature. Today boundaries of comparative literature have been expended by comparative cultural studies. Of course, we have some chance to learn or know progress, methods, and approaches of comparative literature by means of theoretical and practical/applied books I mention above or the other books; however, it can be said that we understand neither its theory and practice nor contributions.

From past today many things have been said on comparative literature up to now, but it will be important to focus on what we will compare. It is very clear that we do not know "what, why or how' we will compare, 'which works or writers' literary worlds must be compared.

Firstly, we must answer these questions if we want to study comparative literature. As well as necessity of a well-defined methodological frame, we must also argue its coverage and search for answers to the questions such as "to whom/what will we compare us /ours? How will we compare the texts? In other words, which texts/writers will we compare? Who are we in the eyes of the others or who are the others in our eyes?" Even though in Spivak's Death of a Discipline the questions "How many are we?" "Who are they?" (Spivak, 2003, p. 70) that she highlights should be observed for the New Comparative Literature which leads us towards comparative cultural studies crossing borders nowadays.

Wellek quotes Van Tieghem's definition of comparative literature in his theoretical book "the object of comparative literature is essentially the study of diverse literatures in their relations with one another" (Wellek, 1970, p. 15) with Van Tieghem's definition. Such an idea opened the doors of different language, culture and literatures behind the boundaries to the scholars. From perspective of comparative literature they began to consider the forerunners, their masterpieces and their influences on each other's in world literature.

In this respect, we can discuss American poet Edgar Allain Poe's influences on world poetry. For instance, a study of Poe's influence on French poet Charles Baudelaire, Baudelaire's influence on English poet T.S. Eliot or Turkish poet Tevfik Fikret. Such a study will be important comparisons between literatures. If the national literatures are isolated from world literature; literary texts' influences, echoes, aspects and values cannot totally be analyzed, detected and judged or evaluated.

In The Preface to Shakespeare, as Dr. Johnson expresses "without the knowledge of many mountains, and many rivers; so in the productions of genius, nothing can be styled excellent till it has been compared with other works of the same kind." (Johnson, 1842, p. 3).

Comparative literature is a key opening all doors beyond the national, cultural, linguistic, historical, social or political boundaries, when we turn our attentions to world literature, we recognize echoes of a masterpiece on our literature or a work of the other nations' literatures as translations and imitations, frequently by second-rate authors, or to the prehistory of a masterpiece, the migrations and the spread of its themes and forms." (Wellek \& Warren, Theory of Literature, 1949, p. 40)

A researcher who studies literatures of other nation(s) to local literature will notice similarities, differences, and developments of the languages, literatures and cultures of two or more nations by comparative approaches; and s/he will find out common themes of the literary texts of different nations. Thus, a comparatist will have a chance to know their 
influences of the texts or the writers on each other's by means of comparative literature.

One of the most common errors in the study of comparative literature in theory and practice is mistake that the writers and their works of literature of a nation could be examined in the light of the science of comparative literature. Each nation may compare its own writers or literary works with each other's, but this is not a comparative literature. This work is a comparative development of that nation's literature; it is a progressive and historical study of the products of a national or local literature. If we want to make comparative literature or a comparative study, we have to compare two or more literatures of the different nations or languages, traditions or cultures.

For instance when we compare English poets, or novelists to each other's, we learn some things about English literature , but when we compare English literature to French literature, American, Russian or Turkish literature we make comparative literature. In that case, aspects, parallels, similarities or developments of English and Turkish poets of ninetieth century may be compared and contrasted by comparative literature or comparative cultural approaches.

Of course, an English poet to another English poet(s) can be compared but as we mention above such a study will explore historical, social or political development, similar and different aspects etc., of English poetry. However when an English poet or writer is compared and contrasted to a Turkish one, this will be a study of comparative literature.

Undoubtedly, to study her own national writers of a country will give information about that country's literature, and this will be a restricted study of an area, but if we want to know other's literature(s( we need literatures of two or more nationalities away from the boundaries of one national language. Moreover as Wellek mentions "we need both literary history and criticism, and we need the wide perspective which only comparative literature can give." (Wellek, 1970, p. 36)

Why will we make compare literature? What are its benefits? To know theory and practice of comparative literature will provide numerous benefits to not only comparatists but also national, general and world literatures.

A comparative study of different literatures will present us rich knowledge of literatures, languages, cultures and identities of other nations, thus comparisons of products of the different literatures will get a chance us to recognize both our values and the other's closely.

Surely while we compare literatures of the different countries or languages we need to break down the borders, we have huge materials to compare synchronically or diachronically literary genres and texts across all times and spaces. We must read, recognize, criticize and evaluate the other nations' literary products. We need to develop, we need to know what the others are doing we must compare ourselves to other's. As Matthew Arnold emphasizes we must have a look at literatures of all periods from classical to postmodern. We recognize similarities and dissimilarities among literatures, and perceive and evaluate the stand they come while we make a study of comparative literature.

We must compare the works of other ages with those of our own age and country; that, while we feel proud of the immense development of knowledge and power of production, which we possess, we may learn humility in contemplating the refinement of feeling and intensity of thought manifested in the works of the older schools. To know how others stand, that we may know how we ourselves stand; and to know how we ourselves stand, that we may correct our mistakes and achieve our deliverance -that is our problem. (Arnold, 1914, p. 457)

On the hand, in a globalized age, importance of the translation studies is undeniable for the science of comparative literature. To study on original texts in their own native languages while poems, epics, tales, stories, novels or essays of different languages are compared and contrasted will be better than their translations.

We all know how difficult a poem to be translated into to another language correctly? If not we know the language of an original text we must have a well translation of the text otherwise we will have to depend on the translated text, and inevitable mistakes will occur in comparisons of the texts. In this regard, to know a second language at least is an important requirement for accurate results in comparative/cultural, linguistic approaches to literatures as well as to learn the methods and techniques of literary analysis and comparison of different national literatures.

After knowing what comparative literature is in theoretical sense, practice of comparative literature can be made on literary genres selected among the literatures of different nationalities. The comparatists must be careful while determining the writers and their literary works of their own literature and other country or countries. They must know very much literary values of countries to be compared.

To give an example for a study of comparative literature, the French symbolist and impressionist poet of Les Fleurs $d u$ Mal (Flowers of Evil) and Le Spleen de Paris, influence of Charles Baudelaire (1821-1867) on T.S. Eliot (1888-1965) in English and Tevfik Fikret (1867-1915) in Turkish will be an appropriate comparison for these modern poets of French, English and Turkish nations.

Baudelaire's influence are not only on Eliot and Fikret, but also on his country's poets and writers such as Mallarmé, Rimboud, Verlaine, Proust; both English ones such as Walter Benjamin, Oscar Wilde, William Butler Yeats, George Moore, Alfred Douglas, Arthur Symons, Arthur Machen; and Turkish ones such as Cenap Şahabettin, Ahmet Haşim, Yahya Kemal, Ahmet Hamdi Tanpınar, Necip Fazıl, Ahmet Muhip Dranas, Cahit Sitkı Taranc1, Attila İlhan; and on the other languages and literatures through the national exchange transcending cultural, socio-political and linguistic boundaries.

Each country has a Baudelaire; this varies according to each critic. All world literatures are in a contact to each other in today's global age. Despite of restricted technology of that period an American or a French writer can have a great influence directly or indirectly on another western, eastern or far Eastern writer. In our age, these kinds of influences will be more than past through mass media and internet. 
Each of these poets is very important for their national literatures in the first place. What about poets of their ages at home and beyond the borders or each other's, even for world literature? Here you need to find the answers to these questions, explore their mysterious aspects in addition to similarities, differences and interactions of their personalities and poetries if we want to make a study of comparative literature.

Baudelaire is well known as one of the world's greatest lyric and symbolist, melancholic poets. Les fleurs du mal has been translated into most Western and Eastern languages and its fame has covered not only his country Frence, but also nearly the whole world. It was translated as Flowers of Evil in English, and as Şer/Kötülük/Elem Çiçekleri in Turkish.

Due to the translations, scholars have recognized inventors of world literature in an easier way. G. Turquet-Milnes made a study named Influence of Baudelaire in France and England (1913), Ali İhsan Kolcu traced his influences in Turkish literature in his book Albatros'un Gölgesi (Shadow of the Albatross, 2002).

These two scholars also examine influence of Baudelaire from perspective of comparative literature. Turquet-Milnes stresses, "His influence has been maintained through fifty years of literary history, and we have found pleasure in listening, in the works of later writers, for the magic echoes of the voice that is still." (Turquet-Milnes, 1913, p. vi) Echoes of this French poet in France and England or the other countries sound in similar ways in Turkey as well. Kolcu also pays attention influences of themes such as spleen, evening, escape, solitude, internal closure, sexuality and erotism in Baudelaire's poetry on Turkish poets. (Kolcu, 2002, p. 449)

In Pul Valéry's words in his conference titled La Situation de Baudelaire (The Position/Place of Baudelaire-19 Feb. 1924) Baudelaire's poetry is "beyond his/our frontiers, it is read throughout the world; taking its place as the characteristic poetry of modernity... Men like Swinburne, Gabriele d'Annunzio, and Stefan George bear magnificent witness to the Baudelairean influence in foreign countries." (Valéry, 1924)

As some poems in Fleurs du Mal (1857) derive their content, form and some materials from Poe's poems, some lines in Waste Land (1922) and Rubab-l Şikeste (Broken Instrument, 1900) are composed and contain some borrowings from Baudelaire'sin.

How important Fikret is as one of the major innovators in Turkish literature, Eliot in English literature, and Baudelaire in French literature are important in the same range more or less. Baudelaire and Eliot are known in European and Asian, American continents so much, but what a pity, as Fikret's works have not been translated into the other languages, and not introduced to world literature his fame is limited to Turkish nations and Turkish writers.

Even Fikret has not completely been understood by his own country's writers and critics or he has been evaluated in a wrong way. He has been accused of being atheist by conservatives. Narrative critical and strong style in his poems, and harsh criticism in his poems such as Sis (Fog), Tarih-i
Kadim (Ancient History), Haluk'un Amentüsü, (The Credo of Haluk) and Promete (Prometheus) in terms of historical, religious and socio-political on monarchy of his age were greeted with disgust by at first his contemporary Mehmet Akif Ersoy.

However, Baudelaire and Eliot have been both translated into several languages their literary values have been understood by native and foreign readers early or late. Our translation agencies are very fast and hasty to translate and introduce a western work, but they are very slow and lazy to do the same thing for their country's ones.

Therefore, the major roles and responsibilities fall to us, academics. Our literary figures are introduced in our articles, books or essays more or less. Here importance of comparative literature is incontrovertible in sense of introducing our literary figures and their works and questioning the stand we are.

In one sense, Fikretism in Turkey is the same way as in Baudelairism in France or Eliotism in England but Baudelairism in England or in Turkey is not the same thing as in France. Of course, this situation is the same for Eliot and Fikret as well behind the borders. Their national tempers are different from the other nationalities' ones.

On the other hand, Baudelairian influence, or the symbolist influence enters through not only Baudelaire, but also Shelley, Mallermé, Verlaine, Rimbaud, Copée into English literature and Turkish. Even Parnassian influence is much more than symbolism on Fikret. Whereas the greatest impact on Fikret at the time came from Copée, on Eliot from Laforgue; Fikret is one of the greatest inventors of free verse (verse libre) in Turkey, and Eliot in England.

When we make a comparison shortly as a practice for comparative literature, although Baudelaire, Eliot and Fikret are poets of different countries, but they have much more similarities rather than differences. We see the poets think and write by similar manners and approaches in both content and form of their poetical styles.

How will we compare these poets? Certainly, we have to know three of them too very well. Later our work will be to focus on their arts. While we compare and contrast Baudelaire, Eliot and Fikret we must study their common aspects, similarities and differences in their interactions with each other

When we examine their poetries we notice they are sick poets due to the spleen of their ages. They are poets of prose-poetry as well as the poets of spleen, sensual, moral and psychological corruptions, spiritual conflicts, and mental and physical illness. They are the poets who compose their poems by symbolist, impressionist, expressionist approaches to the nature, imaginary, sounds, colors etc.,

They are not only poets but also intelligent critics who express their ideas on poetry in several essays. We also meets Parnassian sides in Eliot and Fikret's poetics. Their narrative poems consist of historical, philosophical, social and political issues clearly, but we see spleen, love and pure symbolism rather than these themes in Baudelaire's poems. Mostly he gives importance music, harmony and sensuality rather than 
social problems. This does not mean that others do not value the musicality.

Their common main motto is "art for art's sake" even though we meet socio-political, religious and philosophical criticisms in Eliot and Fikret's poems. London in Eliot's Waste Land and Istanbul in Fikret's Broken Instrument are like Baudelairean Paris spleen in prose poems of Le Spleen de Paris or lyrical poems of Fleurs du mal, Parisian Scenes, love, wine, rebellion, death, flowers of evil, straggles and contrasts between good and evil, measurable people, rich and poor dilemma and so on.

Especially we witness that the notion 'spleen' crossed their works like a deadly illness. Paris spleen touches in English and Turkish poets' poems. London spleen in Waste Land and Istanbul spleen in the famous poem Fog and Iktirab (Sorrowful/ Spleen) in the Broken Instrument that Fikret's poems were collected.

From Greek and Latin periods Homer, Sapho, Catullus to Classical, Modern and Postmodern periods we know the fact that Chaucer, Milton, Shakespeare, Edgar Allan Poe, Baudelaire, Mallarmé, Rimboud, Verlaine, Valery, Yeats, Eliot, Shelley, Keats, Fikret, Yahya Kemal, Ahmet Haşim, Cahit Sitk1 and the others exchanged literary values to national or across the walls, to each other. During the literary history each gave to the other what they had, received from the other what they had not.

Together with Baudelaire and his age is covered by Mal du Siecle (the malady of the century), that is melancholy of their ages passed boundaries. Eliot quotes Webster and Baudelaire in his The Waste Land and enriches his poetical style. In the last stanza of the first section of Waste Land, he includes the last line of Baudelaire's 'Au Lecteur' from the preface to Baudelaire's Fleurs du Mal in his poem: "You! hypocrite lecteur! -mon semblable, - mon frere" (Eliot, 1930, p. 16) Baudelaire wrote the same line "Hypocrite lecteur,- mon semblable,- mon frère!" (Baudelaire, Les Fleurs du Mal, 1857, p. 7) at the end of his poem. Fikret does not quote lines of Baudelaire's poems directly, but he uses a Baudelairian style by similar melancholic language, similar expressions and similar themes in his Rübab-l Şikeste.

Baudelaire describes eight poets- Ruben, Vinci, Rembrandt, Michel-Ange, Puget, Watteau, Goya, Delocroix- in his verse titled "Les Phares" and Fikret also writes six poems subtitled -Fuzuli, Cenap (Şahabettin) Nedim, Üstad Ekrem (Rezaizade Mahmut), Nefi, Hamid (Abdülhak) described the famous poets of Turkish poetry under the section "Aveng-i Tesavir" (Sequence of the Descriptions) (Fikret, 1910, pp. 310-325)

Ali İhsan Kolcu compares poems such as Baudelaire's "Moesta et Errabunda," three 'Spleen' poems, 'Paris Spleen' to Fikret's 'Terennüm' (Singing), 'Bir Ömr-i Muhayyel' (Imaginary of A lifetime), 'Bir an-1 Huzur' (A Moment of Peace), 'Ne Isterim' (What Would I like) and 'Sis' (Fog) (Kolcu, 2002, pp. 121-167), and he touches upon similarities in their themes such as spleen, escape pessimism.

The capitals-Paris, London and Istanbul- of their ages Baudelaire, Eliot and Fikret lived are like each other in their poems. Paris is a city described by "Hospital, brothels, purgatory, hell, prison" ${ }^{1}$ (Baudelaire, 1917, p. 179) in 'Épilogue' of Paris Spleen of Baudelaire. In a similar way, in Fikret's Sis (Fog) Istanbul is also described by its "killer towers, palaces with castles and dungeons" ${ }^{2}$ (Fikret, 1910, p. 291)

London appears with the image of an "Unreal City," a crowd of people who flows over London Bridge echoing Baudelaire's 'Paris le fourmillante tableau' in Eliot's The Waste Land. The city is "under the brown fog of a winter dawn" (Eliot, 1930, p. 14), the fog is covered over the proceedings of the City as if "a stubborn smoke wrapped around her horizons" 3 (Fikret, 1910, p. 289).

Istanbul is cursed by Fikret in the poem Sis (The Fog). This is an imaginative curse due to strict rules of the Sultan Abdul-Hamit of Monarchy of $19^{\text {th }}$ century. Here Istanbul is an image/symbol, in the fact the curse is not to the city, to Monarchical period of the Sultan. "Istanbul, for the first time in Turkish literature in Sis /Fog is considered as a heinous and an accursed city" (Kaplan, 1998, p. 110)

In Fikret's poem, Istanbul is likened to prostitutes, while Baudelaire both loves and hates Paris with all beauty, ugliness and prostitutes: "I love you, infamous capital, bitches" ${ }^{4}$ (Baudelaire, 1917, p. 180) Baudelaire accepts this infamous city steeped in sin, reminded him of purgatory and a hell, with its whorehouse, prisons with all bad sides. Nevertheless, Fikret is in a strong hatred to Istanbul. "It is the fusty Byzantine, an old, a charming fool, a widowed girl, residue of a thousand husbands." ${ }^{5}$ (Fikret, 1910, p. 290)

In Paris, London, Istanbul there are spleen, death, killers, bandits, gates of hell. The poets want to escape from the cities they live in, but they do not go anywhere, they cannot go away. Paris and London are charming despite of everything, but Istanbul does not fascinate Fikret. Is is full of hypocrisy, dirt, loathsome, envy." The poet humiliates and curses Istanbul during the poem by the words "Cover/Drap (city), and eternal sleep, O world's old bitch!"

London of Eliot is a dead city. People are impotent; they are in conflict between life and death. The poet describes the city by the lines "Sighs, short and infrequent, were exhaled, and each man fixed his eyes before his feet. Flowed up the hill and down King William Street, To where Saint Mary Woolnoth kept the hours With a dead sound on the final stroke of nine" (Eliot, 1930, p. 15)

Paris is a 'gate of Hell', London is a 'waste land', and Istanbul is an old bitch. They are wastelands, the cities of spleen; shortly their people are 'hollow men' by words of Eliot in one sense. Of course, there are many things about these three poets and their poetries. Here I wanted to explain main aspects so that they are a practice for comparative literature.

\footnotetext{
1 Hôpital, lupanars, purgatoire, enfer, bagne

2 Katil kuleler, kal'eli, zindânlı saraylar

3 Sarmış yine âfakını bir dûd-ı mu'annid

4 Je t'aime, o capitale infâme! Courtisanes

5 Ey köhne Bizans, ey koca fertût-1 musahhir, Ey bin kocadan artakalan bîve-i bâkir;
} 


\section{Conclusion}

From Plato and Aristotle's ages to present people have been interested in the others' literature, languages, cultures or customs, they have made some comparisons between themselves and the others.

In academic respect since 19th century comparative literature has been developed and theorized, the science of comparative literature has been transformed in one side into the theories of comparative literature and literary criticism, comparative literature as an umbrella term has focused on world literature in some curiosity of knowledge the self and the other.

While Wellek and Warren govern the principles and practices of comparative literature, Totosy de Zepetnek offers a method in at least two ways for the discipline of Comparative Literature. First comparative literature means the knowledge of more than one national language and literature, and/or it means the knowledge and application of other discipline in and for the study of literature and second, Comparative Literature has an ideology of the inclusion of the Other, be that a marginal literature in its several meanings of marginality, a genre, various text types, etc. (Tötösy de Zepetnek, 1998, p. 13)

We can ask some questions such as what does "comparative literature" mean? or which cultures, languages or whose literatures is it concerned? Does it have any relationship the concept of "world literature"? or What sorts of relations does a national literature have to the international ones? What about comparative approaches to world literature?

Where will these kinds of questions bring us? Is a passage to comparative literature in all countries? Who is interested in it? or what contribution/s does comparative literature provide to us.

On Wednesday, on 31 January 1827, over dinner, Goethe talks to Eckermann "about especially a Chinese novel that he has read many and various things; which occupies him still, and seems to him very remarkable." As a reaction," that (Chinese novel) must be very strange enough," says Eckermann. However Goethe's respond "Not so much as you might think" will be, and Goethe's comparative approach will go on Chinese, German and English novelists:

"The Chinamen think, act, and feel almost exactly like us; and we soon find that we are perfectly like them, excepting that all they do is more clear, more pure, and decorous than with us. With them all is orderly, citizen-like, without great passion or poetic flight; there is a strong resemblance to my 'Hermann and Dorothea,' as well as to the English novels of Richardson. They likewise differ from us, inasmuch as with them external nature is always associated with the human figures. You always hear the goldfish splashing in the pond, the birds are always singing on the bough, the day is always serene and sunny, the night is always clear." (Goethe, 1850, p. 349)

Comparative literature is a unique tool for readers or academics or researchers who feel curious, enjoy reading and analyzing literary works about other languages and cultures of the other nations, or interested in global studies and international relations.

As we said before, the most important aspect of comparison a literary text must be the products of different nations, cultures or languages. A comparatist can study literatures from all parts of the globe, there is no boundary, he or she can go beyond one nation's literature, she / he compare it to two or more, for instance someone who studies Turkish language and literature can understand foreign language, culture or literary works in their original languages such as English, French, German, Spanish and Chinese.

Comparative literature will help us explore all literary values of the other literatures as well as ours. Whereas it is necessary not to forget that the works of the same nation will not be a study of comparative literature, it is a literary study, a comparative approach to literary history of a national literature, not comparative literature. It means progress of a country's own literature, a literary research. However comparative literature is a study behind the boundaries, between different languages, cultures and literatures .

To sum up, what benefits comparative literature provides us are obvious as we discuss above. Comparative literature is necessary for the world literature. We can examine importance of Voltaire for French, Spencer for English, Dante for Italian, Tolstoy for Russian, Al-Farabi for Turkish; and all of them importance for the world literature in the light of comparative literature in the best way.

\section{References}

[1] Arnold, M. (1895). In G. W. Russell, Letters of Matthew Arnold 1848-1888 1 (2 vols). London, London: Macmillan and Co.

[2] Arnold, M. (1914). On the Modern Elements in Literature. In Essay by Matthew Arnold Incluiding Essays in Criticism, 1865 On Translating Homer and Five Other Essays (pp. 453-472). London: Humphrey Milford, Oxford University Press.

[3] Baldensperger, F. (1921). Littérature Comparée: Le Mot et la chose. In F. Baldensperger, \& P. Hazard, Revue de Littérature Comparée 1 (pp. 5-29). Paris: Librairie Ancienne Honoré Champion Edouard Champion.

[4] Baudelaire, C. (1857). Les Fleurs du Mal. Paris: Poulet-Malassis et de Broise.

[5] Baudelaire, C. (1917). Petits Poemes en Prose (Le Spleen de Paris). Paris : Louis Conard.

[6] Eliot, T. (1930). The Waste Land. New York: Horace Liveright.

[7] Fikret, T. (1910). Rübab-ı Şikeste. İstanbul: Tanin Matbaası.

[8] Goethe, J. W. (1850). Conversations of Goethe with Eckermann and Soret. Trans From German by John Oxenford in Two Volumes (Vol.1). London: Smith, Elder and Co.,

[9] Johnson, D. (1842). Dr. Johnson's Preface. In W. Harness, The Complete Works of William Shakespeare with Dr. Johnson's Preface (pp. 3-10). London: Scott, Webster, and Geary.

[10] Kaplan, M. (1998). Şiir Tahlilleri I. İstanbul: Dergah Yayınları. 
[11] Kolcu, A. İ. (2002). Albatros'un Gölgesi. Ankara: Akçağ.

[12] Meres, F. (1598). A Comparative Discourse of our English Poets, with the Greek, Latin, and Italian Poets, http://www.elizabethanauthors.org/palladis.htm

[13] Shakespeare, W. (1773). The Plays of William Shakespeare. London: C. Bathurst.

[14] Spivak, G. C. (2003). Death of a Discipline. New York: Colombia University Press .

[15] Tötösy de Zepetnek, S. (1998). Comparative, Literature, Theory, Method, Application. Amsterdam-Atlanta: Rodopi.

[16] Tötösy de Zepetnek, S. (1999). From Comparative Literature Today toward Comparative Cultural Studies. CLCWeb:
Comparative Literature and Culture, Vol. 1, Issue 3, http://docs.lib.purdue.edu/cgi/viewcontent.cgi?article=1041\&c ontext $=$ clcweb.

[17] Turquet-Milnes, G. (1913). The Influence of Baudelaire in France and England. London: Constamble and Company Ltd.

[18] Valéry, P. (1924). Situation de Baudelaire. Paris: Chez Madame Lesage (it was also published in Variété II , Paris, NRF, 1930, p. 134-135).

[19] Wellek, R. (1970). Discriminations: Further Concepts of Criticism. Delhi: Vikas Publishers.

[20] Wellek, R., \& Warren, A. (1949). Theory of Literature. New York: Harcourt. 